\title{
4. $\quad$ Economic sustainability of national parks in the Congo Basin: A case study of the Sangha Tri-national Park
}

\author{
Julius Chupezi Tieguhong and Janusz Zwolinski \\ Forestry, Faculty of Science \& Agriculture, University of KwaZulu-Natal, P Bag X01, Scottsville \\ 3209, South Africa. chupezi@yahoo.co.uk or 204523366@ukzn.ac.za \\ zwolinskij@ukzn.ac.za Tel.+27-33-2606007 Fax.+27-33-2606005
}

\begin{abstract}
The second largest complex of tropical rain forest is located in the Congo Basin. This forest is renowned for its biodiversity, harbouring thousands of rare species of plants and animals and providing environmental services at a global level. At the same time these forests are of critical importance to the people of the region. The local economies depend on timber harvesting, while the forest dwellers support their subsistence with forest products on daily basis. The dilema faced by policy makers, conservationists and the local communities is in merging the various ideals, objectives and needs at a local, national and global level in order to sustain the forests, their fauna and the people. Examples from Southern and Eastern Africa have shown that, with the right management in place, natural ecosystems managed jointly for ecotourism, conservation and recreation, can yield appreciable benfits at minimum environmental destruction. Therefore it is believed that well-organized tourism can become the best way to use the Congo Basin's forests for creating economic opportunities without destroying the resources. The challenge therefore, is in convincing decision-makers that conservation of forests can provide for sustainable economic development. However in the Congo Basin this potential has not been demonstrated thus far. Deliberate policy initiatives to cost recovery, profit making or generation of local business are woefully lacking. Not only are the protected forests maintained with marginal funds, but the management systems in place are also ineffective, especially regarding poor financial management resulting in losses of $2 / 3$ of the expected revenue. The centralized collection and distribution of funding by government agencies prevents local initiatives from achieving financial sustainability. It also remains unclear how the fees paid by tourists visiting the parks are related to the operational costs and if these fee structures do in fact approximate tourists' willingness-to-pay (WTP). In this study the factors of (i) tourists' WTP higher entrance fees and (ii) duration of stay, were evaluated in two protected areas of the $28000 \mathrm{~km}^{2}$ Sangha Tri-National Park shared by Cameroon, the Republic of Congo and the Central African Republic. It was found that if park facilities were improved the potential entry fee in the Lobeke National Park could be increased by an additional US\$ 10 per visitor. At the Dzanga-Ndoki National Park, foreign, resident and national tourists could be paying an additional US\$ 30, 20 and 7, respectively. To this end improvements in park facilities, efficiency in entrance fee setting and management structures are recommended.
\end{abstract}

Keywords: contingent valuation method, ecotourism, entrance fee, revenue management, visitation, willingness-to-pay

\section{Introduction}

African countries face huge challenges of poverty, wars, hunger corruption and unlawfulness and yet the objective of protecting forests is their high priority. Despite a criticism of weak political will and ineffective funding mechanisms for this cause (Tieguhong and Ndoye, 2004) there are various progressive intergovernmental agreements and supportive policy documents including: (i) a Conference on Central African Moist Forest Ecosystem, known as the Brazzaville Process of 1996, with various stakeholders from 10 African countries attending; (ii)the Yaounde Process of 1999 and its 12-point agenda (incl. creation of trans-boundary protected areas, inclusion of business, 
promotion of sustainable processing, and strategies for sustainable financing) supported by seven heads of state; (iii) the Central African Forestry Commission started in 2000 and which is now known as the Council of Ministers; (iv) the Congo Basin Forestry Partnership - a free association of 33 stakeholder organizations operating in six countries in the Congo Basin since 2002 (CBFP, 2006; COMIFAC, 2005).

The most extensive complex of African indigenous forests is located in the Congo Basin where $57 \%$ of the 398.3 million ha is covered by tropical rainforests. In combination with a relatively low population density $\left(20\right.$ persons $/ \mathrm{km}^{2}$ ), this gives the region an average of 2.9 ha of forests per capita compared to the global average of $0.8 \mathrm{ha}$ /person (FAO, 2005). It is not surprising, therefore, that these forests are among the most important economic assets based on which jobs and external revenues are generated. At the same time this second largest complex of tropical rainforest in the world contains unique flora and fauna and therefore attracts attention of many environmental lobbies. Thus $14.4 \%$ of the area is currently protected against ruthless exploitation in 49 national parks (Table 1) (Nasi et al., 2006; FAO, 2005).

The cost of preserving these forest in terms of their protection, management and lost revenue is enormous, especially for the poverty stricken forest dwellers and budgets of the affected countries. Among the various management options for income generation, ecotourism and recreation have been shown to generate appreciative revenues in southern and eastern African countries with relatively little destruction to the environment. Despite that huge potential, economic sustainability of these protected areas has not been achieved in the Congo Basin due to inadequate policies and their implementation, marginal cost recovery, no profit making and lost business opportunities. According to James (1999) and Wilkie et al. (2001) budget allocations for the management of protected areas in the region ranked among the lowest in the world and ranged between 8 and 30 US\$/ha compared to over $2000 \mathrm{US} \$ /$ ha in South Africa and Kenya. Therefore one way of improving tourism and in turn the profitability of the parks is by increasing funding, staff numbers and service quality (James, 1999). The centralized approach in collecting and distributing money by the state is also criticized as inefficient (Spergel, 2001). Internal generation and the control of funding from fees, concessions, accommodation, rentals, selling of merchandise and others should stimulate proper pricing, marketing and income policies (Tieguhong, 2003).

Table 1. The extent of protected forests in the Congo Basin.

\begin{tabular}{lccc}
\hline \multirow{2}{*}{ Country } & $\begin{array}{c}\text { Number of } \\
\text { national parks }\end{array}$ & Area (ha) & $\begin{array}{c}\text { Proportion of forest } \\
\text { area (\%) }\end{array}$ \\
\cline { 3 - 4 } & 14 & 3227361 & 14 \\
\hline Cameroon & 5 & 5017000 & 22 \\
Central African Republic & 9 & 16141650 & 12 \\
Democratic Republic of Congo & 3 & 552000 & 32 \\
Equatorial Guinea & 14 & 3955285 & 18 \\
Gabon & 4 & 3819002 & 17 \\
Republic of Congo & 49 & 32712298 & 14.4 \\
\hline Total & & & \\
\hline
\end{tabular}

Overall, the national parks in the Congo Basin are constantly faced with three major difficulties (Blom, 2004; 2001; Wilkie et al., 2001; Blom, 2000; Wilkie and Carpenter, 1999a\&b):

- inadequate funding to cover the recurrent costs and investments needed to modernize the infrastructure, to advertise and to attract more tourists. With only $30 \%$ of operating costs being covered by state subsidies and erratic funding from international sources, the numbers of visitors and tourism-derived revenues have remained stagnant in recent decades;

- lack of effective and accountable financial management systems resulting in poor collection of fees, inefficient accounting and corrupt practices at a loss of $2 / 3$ of the potential revenues from entrance fees and services; 
- no business plan relating the operational and social costs, values and services to the current and prospective income from fees paid by tourists and their willingness-to-pay (WTP) higher fees as well as from other business opportunities.

Despite the opaque picture and stagnation, hopes may not be lost because prospects of improving ecotourism in the region remain very high (Yunis, 2003). In order to circumvent the abovementioned difficulties, innovative strategies need to be developed to generate more sustainable funding and transparent accounting systems. Concomitantly, efficient fee setting, collection and financial management for all the protected areas are needed in the region.

In this study higher entry fees paid by the tourists and their prolonged visits were evaluated in two protected areas of the Sangha Tri-National Park shared by Cameroon, the Republic of Congo and the Central African Republic (CAR).

\section{Study area and methods}

After the Yaounde Declaration had been signed by the Heads of six Central African countries (COMIFAC, 2005), the forestry ministers of Cameroon, the CAR and the Republic of Congo established the Sangha Tri-National Park, known by its French acronym as 'Trinational de la Sangha' (TNS) in 2000. The TNS comprises of the Lobeke National Park (LNP) in Cameroon, the Dzanga-Ndoki National Park (DNNP) and the Dzanga-Sangha Special Reserve in the CAR, and the Nouabale-Ndoki National Park in the Republic of Congo. The objective behind this initiative was to protect natural resources on this $28000 \mathrm{~km}^{2}$ of land by harmonizing forestry laws and putting into place a common management system, anti-poaching measures, ecological monitoring, scientific research, communication and logging controls (Usongo, 2002). In general, the principles of a sustainable forest management system are founded on balanced considerations of economic, social and ecological dimensions. With regards to the TNS, the ecological and ethnographic findings have been well documented in various reports (CBFP, 2006; van Germerden, 2004; Usongo, 2002; 1998) but very little, or nothing is known about its socio-economic dimensions. The TNS was established as a model park from which some generalisations should be drawn for other protected areas in the Congo Basin and beyond.

The data for this study was collected in the LNP and the DNNP by applying a questionnaire to tourists visiting the Parks. A stratified random sampling technique (Clairin and Brion, 1997) was applied for collecting data from two categories of tourists (national and foreign) in the LNP and three categories (national, resident and foreign) in the DNNP. The proportion of tourists in each category was calculated from the historical records kept by Park management. Questions in this survey were divided into four categories: (i) environmental issues, (ii) recreational activities, (iii) entry fees, and (iv) personal information.

The current entrance fee was used as a reference, and then increased by $100 \%$ and by $200 \%$. The tourists were asked a question on the higher entry fees to obtain responses in the double bounded dichotomous format. Each time, motivational information was repeated for each tourist. A pilot study was conducted to ensure that questions are clearly understood and acceptable to the respondents. This questionnaire was administered in person to make sure that all questions are answered. As recommended by Loomis and Gonzales-Caban (1997) this survey targeted not less than 200 tourists over a period of 12 months in the LNP and 8 months in the DNNP.

The collected data was entered into Microsoft Excel for Windows 2003 and analysed by using STATA version 8 and SPSS version 12 (SPSS User Guide, 1999) to obtain primary statistics and to conduct binary logistic regression analysis. The bi-probit model was used to test a dependence of $100 \%$ or $200 \%$ increase in entrance fees in relation to the demographic characteristics of the tourists. A contingent valuation method (CVM) was selected to define the willingness to pay (WTP) entry fees. This method varies from various valuation techniques (Amigues et al., 2002; Eagles et al., 2002; Pieter et al., 2002; Brown, 2001) because it is simple, commonly applied and used to estimate the values of both market and non-market goods and services including "artificial 
markets"(hypothetical markets). Contrary to the "travel cost value method" the CVM can be used on "direct use values", such as forest recreation (Mohd Azim et al., 2002; Hu Mingxing, 1998). This method has increased in popularity worldwide because of its reliable outcomes (Lindberg 2001, Eagles et al., 2000; Hackett, 2000; Hu Mingxing, 1998; Israngkura, 1998; Lindberg and Johnson, 1994). Six major steps are followed when applying the CVM (Whitehead, 2003; Adamowicz et al., 1998; 1997;): (i) setting a realistic hypothetical scenario; (ii) setting WTP questions, (iii) setting questions on the socio-economic and demographic characteristics of visitors, (iv) designing the survey, (v) implementing the survey and (vi) compiling the data, analyzing and reporting the results. Once the data had been generated, an average WTP value (a hypothetical market price for future visits to the Parks) was estimated according to the utility theory of value (Hu Mingxing, 1998) from the mean and median WTP and the current and projected numbers of tourists, based on their responses to theoretically improved infrastructure:

$$
\mathrm{WTP}=\sum_{i=1}^{k} \mathrm{AWP}_{\mathrm{i}} *\left(\mathrm{n}_{\mathrm{i}} / \mathrm{N}\right)^{*} \mathrm{M}
$$

where:

WTP - total willingness to pay for forest recreation by tourists

$\mathrm{AWP}_{\mathrm{i}}$ - willingness to pay at entry fee level i

$\mathrm{n}_{\mathrm{i}} \quad$ - total number of tourists surveyed whose WTP is AWP $\mathrm{i}_{\mathrm{i}}$

$\mathrm{N} \quad$ - total number of tourists surveyed

M - total number of foreign tourists.

Finally a tax maximisation principle was applied to calculate the maximum revenue associated with the optimum entrance fees as visitation increases. The tax maximisation technique was introduced by Arthur Laffer (Lecaillon and Pondaven, 1998) who stated that by increasing a tax rate, the revenue increases but only until a certain optimum tax rate is reached. After that optimum value, the revenue decreases because of tax evasions or a relocation of businesses (Figure 1). Cartesian curves were plotted with the entrance fee revenue (EFR) calculated from entrance fees and numbers of visitors in each category, from which the optimum entrance fee was determined for each category of tourists (Schultz et al. (1998). This is in accordance with Laffer who stated that there is no equation that permits the estimation of the optimum tax and that it can be done only by using graphical observations (Lecaillon and Pondaven, 1998).

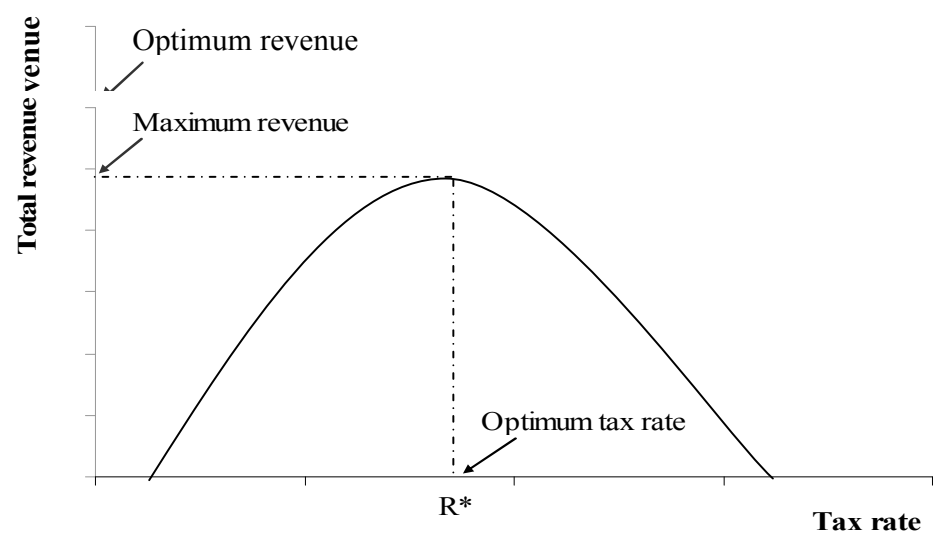

Figure 1. "Laffer's Curve" showing a change of tax revenue with increased tax rates (Lecaillon and Pondaven, 1998).

\section{Results and discussion}

In 2006, 300 tourists visited the LNP and 1042 tourists entered the DNNP. In both Parks the majority of tourists came from other countries while only $21 \%$ of the visitors in the LNP and $16.9 \%$ in the DNNP were locals. In the LNP the foreign visitors came mainly from Germany (17.1\%), USA (15.2), France (12.7\%), Spain (9.5\%), Great Britain (8.8\%) and 21 other countries. The DNNP 
was visited by 11 nationalities including visitors from Spain (31.5\%), Sweden (24.1\%), France (14.8\%), USA (5.6\%), Norway and Belgium (3.6\% each). Most tourists (79\%) were of medium age (30 to 50 years) and 41.5\% (LNP) and 33.3\% (DNNP) of all the tourists were females. Most tourists, especially the foreign tourists, were well educated. Despite that the foreign tourists stayed longer in Cameroon (9.1 days) than in the CAR (7.9 days), their visits to the LNP were usually shorter than to the DNNP. It is likely that there are more attractions in Cameroon than in the CAR or that the DNNP may provide more comfort for prolonged visits (Blom, 2004). The unstable political situation in northern CAR possibly was also preventing tourists from staying longer in this country. Most tourists were interested firstly in wildlife and then in Pygmy culture and the rainforest, and their activities focused on observations of wildlife, nature photography and hiking. There were only a few visitors returning to the Parks while the majority of the tourists visited the area for the first time. Approximately $44 \%$ of the tourists indicated their interests in returning to the Parks while 20\% and 25\% did not intend to return to the LNP and the DNNP, respectively. Poor management and organization were usually given as the reason for dissatisfaction in the LNP while poor roads, infrastructure and harassments by the police were repelling visitors from returning to both Parks (Table 2). All tourist categories expressed interest in longer visits to the Parks if their facilities were to be improved. On average visits could be prolonged by 1.9 days in the LNP and 1.5 days in the DNNP. Most of the tourists supported higher entrance fees except for the resident tourists visiting the DNNP (Table 3).

Table 2. Percentage of tourists dissatisfied with various aspects of their stay in the Lobeke (LNP) and Dzanga Ndoki (DNNP) National Parks.

\begin{tabular}{lcc}
\hline \multicolumn{1}{c}{ Improvement needs } & LNP & DNNP \\
\hline Roads and bridges & 15.1 & 23.5 \\
Information & 13.3 & 0 \\
Transparent accounting & 8.8 & 8.8 \\
Organization and management & 8.1 & 2.9 \\
Qualifications of staff and guides & 8.1 & 0 \\
Functioning of police & 6.7 & 0 \\
Poaching control & 6.0 & 2.9 \\
Accommodation & 6.0 & 0 \\
Road traffic & 4.9 & 52.9 \\
Communication network & 4.2 & 0 \\
Toilets & 3.9 & 0 \\
Restaurants & 3.9 & 0 \\
Camps & 3.5 & 5.9 \\
Watchtowers & 3.5 & 0 \\
Water supplies & 2.1 & 0 \\
Sanitation & 1.4 & 2.9 \\
Other facilities & 0.7 & 0 \\
\hline
\end{tabular}

Table 3. Proportion of tourists willing to pay more (WTP) for recreation in the Lobeke and Dzanga-Ndoki National Parks by various tourist category.

\begin{tabular}{lccccccr}
\hline \multirow{2}{*}{ WTP } & \multicolumn{3}{c}{ Lobeke National Park } & \multicolumn{4}{c}{ Dzanga Ndoki National Park } \\
\cline { 2 - 8 } & National & Foreign & All & Foreign & National & Resident & All \\
\hline Yes & 85.7 & 84.2 & 84.5 & 81.5 & 78.6 & 53.3 & 75.9 \\
No & 14.3 & 15.8 & 15.5 & 18.5 & 21.4 & 46.7 & 24.1 \\
\hline
\end{tabular}

This qualitative information on the WTP higher fees appeared promising for the improvement to the Parks' finances but insufficient to justify policy changes regarding the fees in the Parks. It was therefore considered important to make quantitative estimates on the actual amount of money that tourists would be willing to pay if park facilities, infrastructure and organization was to be improved. This was done with the use of the dichotomous choice contingent valuation method. The 
results showed a prospective improvement in the income from the entrance fees of between $46 \%$ and $149 \%$ depending on a tourist category (Table 4 ).

Table 4. Consumer surplus (US\$) for various categories of tourists visiting the Lobeke and the DzangaNdoki National Parks based on the current entrance fees and the willingness to pay (WTP) entrance fees calculated with the contingent valuation method.

\begin{tabular}{lccccc}
\hline \multirow{2}{*}{ Category } & \multicolumn{2}{c}{ Lobeke National Park } & \multicolumn{3}{c}{ Dzanga-Ndoki National Park } \\
\cline { 2 - 6 } & Foreign & National & Foreign & National & Resident \\
\hline Current fee & 10 & 4 & 30 & 3 & 20 \\
WTP fee & 18.65 & 9.95 & 53.6 & 4.9 & 29.3 \\
\hline Surplus & $\mathbf{8 . 6 5}$ & $\mathbf{5 . 9 5}$ & $\mathbf{2 3 . 6}$ & $\mathbf{1 . 9}$ & $\mathbf{9 . 3}$ \\
\hline
\end{tabular}

Foreign tourists offered the highest fees to enter the Parks. This could be justified by the fact that foreign tourists come from afar with well-calculated budgets to spend on recreation. This could also be linked to their higher income levels as compared to national and resident tourists.

Before the biprobit analysis was performed, all the qualitative independent socio-economic variables were dichotomized as follows: age (i) young and (ii) old ( $>40$ years); gender: (i) males and (ii) females; marital status: (i) single and (ii) married, divorced and widowed; membership of conservation organizations: (i) member and (ii) non-member; education level: (i) standard and medium, and (ii) high; connectivity: (i) frequent visitor and (ii) first-time visitor; destination choice: (i) planned and (ii) incidental; trip organization: (i) self-organized and (ii) agent-organized; other destinations: (i) multiple destinations and (ii) singular destinations; awareness of TNS organization: (i) aware and (ii) not aware. A correlation matrix for foreign and national tourists showed that some of the independent variables were strongly auto-correlated and therefore they had to be dropped from the model. An individual decision was made on retaining or dropping variables which were only slightly auto-correlated.

The following variables were selected for foreign tourists visiting the LNP: annual income, marital status, age, gender, frequent visitor status, membership of conservation organisations, party composition, level of education, other destinations, trip organisation and destination choice. The biprobit model for national tourists to the LNP was based on four variables: annual income, party composition, frequent visitor status, and destination choice. In the DNNP the following variables were included in the biprobit models: (i) for foreign tourists - income, age education level, marital status, trip organisation, destination choice, and frequent visitor status; (ii) for national tourists education level, annual income, trip organisation and destination choice and (iii) for resident tourists - annual income, marital status, trip organisation, and membership of conservation organisations. Coefficients of the significant $(\mathrm{p} \leq 0.05)$ independent variables for each park, tourists category and additional fee combinations are provided in Table 5.

Annual income was the only variable positively associated with the WTP higher entrance fees across most of the tourist categories. This is possibly also the reason while older tourists were prepared to pay more as older tourists were usually characterized by higher income. Married visitors were also inclined to pay more as most likely they used combined incomes to cover the costs of their trips. National tourists traveling alone or visiting specific parks can also pay additional fees. Tours organized by tour operators are costly and tourists expect that all their costs are covered. This was not the case in the DNNP where self-organized tourists were associated with a lower probability of willingness to pay higher entry fees. Tourists re-visiting the DNNP have been appreciative of improvements in the Parks and therefore they were supportive of higher entry fees. On the other hand the frequent visitors to the LNP and members of conservation organizations were dissatisfied with the state of the Park not believing that elevated fees would be used to upgrade the Park. Therefore the probability of increasing the fees would be reduced by them. 
Table 5. Coefficients of independent variables significant $(\mathrm{p} \leq 0.05)$ in the biprobit models explaining willingness to pay by tourists higher entry fees in two national parks of the Congo Basin by various tourist category.

\begin{tabular}{|c|c|c|c|c|c|c|c|c|c|c|}
\hline \multirow{3}{*}{ Variables } & \multicolumn{4}{|c|}{ Lobeke National Park } & \multicolumn{6}{|c|}{ Dzanga-Ndoki National Park } \\
\hline & \multicolumn{2}{|c|}{ Foreign } & \multicolumn{2}{|c|}{ National } & \multicolumn{2}{|c|}{ Foreign } & \multicolumn{2}{|c|}{ National } & \multicolumn{2}{|c|}{ Resident } \\
\hline & US\$10 & US\$20 & US\$4 & US\$8 & US\$30 & US\$60 & US\$3 & US\$6 & US20 & US\$40 \\
\hline Annual income & 0.0012 & 0.0006 & 0.0001 & - & 0.00003 & 0.00001 & - & - & 0.0001 & - \\
\hline Marital status & - & -0.575 & - & - & - & -0.768 & - & - & 1.478 & 0.798 \\
\hline Frequent visitor & - & -0.940 & -2.407 & -.8 .190 & 1.157 & 1.075 & - & - & - & - \\
\hline Member of conservation & - & -1.005 & - & - & - & - & - & - & -1.098 & - \\
\hline Party composition & - & - & 5.896 & - & - & - & - & - & - & - \\
\hline Destination choice & - & - & 1.184 & 0.920 & - & - & - & - & - & - \\
\hline Age & - & - & - & - & -0.971 & -0.718 & - & - & - & - \\
\hline Trip organization & - & - & - & - & -1.045 & - & 0.857 & - & -0.807 & -1.214 \\
\hline
\end{tabular}

The optimum entrance fees defined from the EFR (Laffer's) curves were US\$ 20 and US\$ 14 for the LNP foreign and national tourists, respectively, and US\$ 60, US\$ 10 and US\$ 40 for the DNNP foreign, national and resident visitors, respectively. Therefore, the adjusted consumer surplus based on these entrance fee values was slightly higher than the CVM based consumer surplus values: in the LNP the method yielded an additional US\$ 10 for any tourist category and an extra of US\$30, US\$ 7 and US\$ 20 for the foreign, national and resident tourists in the DNNP.

\section{Conclusions}

A combination of widely understood sustainable forest management must be founded on the environmental, social and economic principles. Tourism is a unique way of natural resource utilization which integrates all three principles if correctly applied. The major challenge to the conservation of tropical rainforests in the Congo Basin is to convince the policy makers that regional development can be achieved without destruction to indigenous resources.

The Sangha Tri-National Park is an international milestone in forest conservation. Yet, its success will depend on how well all the objectives of sustainability are achieved. This analysis should help in making strategies on the management and organization of the Park as well as in pricing policies focused on specific customer groups. In the most general terms, the entrance fees are predominantly based on the tourists' ability to pay but also on the value for money which is associated with park facilities and service quality. Immediate improvements to the Park's financial situation can be made by adjusting the entrance fees as documented in this study. With an efficient fee collection, management and pricing, the LNP can realise an additional annual revenue of US\$ 6566 while additional US\$ 84985 could be earned in the DNNP. To achieve that however, substantial changes in management, financial accounting and organization need to take place. In the immediate future investments should be made to improve the infrastructure, accessibility, hygiene and safety of visitors to the Parks.

\section{Acknowledgements}

Sincere gratitude goes to two field enumerators: John Ndakwe Mukiawah in Mambele and Anicet S.Lebiangali in Bayanga, who were very enthusiastic to administer questionnaires to tourists in the field. We cherish and heartily appreciate a number of friends and colleagues: Guy Paulin Tekombong and Bruno Bokoto, for their ideas and knowledge that was very valuable in data analysis and the production of the map. We acknowledge, appreciate and thank the French Cooperation, the International Foundation of Science (IFS) and the African Forestry Research Network (AFORNET) for funding all field research work, and CIFOR and the University of KwaZulu-Natal for efficiently managing the funds. 


\section{References}

Adamowicz W.L., J. Swait, P.C. Boxall, J. Louviere, and M. Williams. 1997. Perceptions versus objective measures of environmental quality in combined revealed and stated preference models of environmental valuation. Journal of Environmental Economics and Management 32: 65-84.

Adamowicz W., P. Boxall, M. Williams and J. Louviere. 1998. Stated Preference approaches for measuring passive use values: Choice Experiments and Contingent Valuation. American Journal of Agricultural Economics 80:64-75.

Amigues J.P., Boulatoff C., Desaigues B., Gauthier C. and J.E. Keith. 2002. The benefits and costs of riparian analysis habitat preservation: a willingness to accept/willingness to pay contingent valuation approach. Ecological economics 43 (9): 17-31.

Blom A. 2000. The monetary impact of tourism on protected area management and the local economy in Dzanga-Sangha (Central African Republic). Journal of Sustainable Tourism 8:175-189.

Blom A. 2001. Ecological and economic impacts of gorilla-based tourism in Dzanga-sangha, Central African Republic. PhD Thesis. University of Wageningen, Wageningen, Netherlands. ISNN: 0926-9495. pp 142-156.

Blom A. 2004. An estimate of the costs of an effective system of protected areas in the Niger Delta - Congo Basin Forest region. Biodiversity and Conservation 13: 2661-2678.

Brown C.R. 2001. Visitor Use fees in protected areas: Synthesis of the North American, Costa Rican and Belizean Experience. The Nature Conservancy Report Series Number 2. www.conserveonline.org/2001/06/s/CORYFNL;internal\&action=cs.plain.action. Last visited $11 / 10 / 2006$.

CBFP (Congo Basin Forest Partnership). 2006. The Forests of the Congo Basin. State of the forest. COMIFAC. 256 pp.

Clairin R. and Brion P. 1997. Manuel de sondage. Applications aux pays en voie de développement. Paris, 2e edition. Centre Français sur la population et le développement. 108pp. ISBN: 2-87762-109-X.

COMIFAC 2005. Treaty on the conservation and sustainable management of forest ecosystems in Central Africa and to establish the Central African Forests Commission. February. 17 pp.

Eagles P.F.J., D. Mclean and M.J. Stabler. 2000. Estimating the tourism volume and value in parks and protected areas in Canada and the USA. The George Wright Forum. Vol.17(3): 62-82. www.georgewright.org/173eagles.pdf

Eagles P.F.J., McCool S. F. and C.D. Haynes. 2002. Financial aspects of tourism in protected areas. In: Sustainable Tourism in Protected Areas: Guidelines for Planning and Management. A. Phillips (Ed.). PP.119-142. tpp://159.189.176.141/xm1/BestPractices/ TBP-3.pdf

FAO. 2005. State of the World's Forests. FAO. Rome. ISBN: 92-5-105187-9. 153 pp.

James A.N. 1999. Institutional constraints to protected areas funding. Parks: The International Journal for Protected Area Managers. Vol.9. (2): 15-33.

Hackett C.S. 2000. The recreational economic value of the Eastern Trinity Alps Wilderness. http://www.hunboldt.edu/ envecon_423/trinityAlps.html. last visited 27/03/07.

Hu Mingxing. 1998. Review on several methods for evaluating forest recreation. In: Forest environmental value accounting. Hou Yuanzhao, Zhang Ying and Li Yumin (Eds.) ITTO PD $39 / 98$ Rev.2 (M). Pp. 103-111.

Israngkura A. 1998. Environmental valuation: an entrance fee system for national parks in Thailand. The School of Development Economics, National Institute of Development Administration (NIDA), Serethai Road, Bangkapi, Bangkok 10240, Thailand.

Lecaillon J. and Pondaven C. 1998. Analyse micro-economique, Theories economiques. Editions CUJAS. $332 \mathrm{pp}$.

Lindberg K. 2001. Protected area visitor fees. Overview. 6 August Version. www.ecotourism.org/pdf/proareafees country.pdf. Last visited 24/11/06.

Lindberg K. and R.L. Johnson. 1994. Estimating demand for ecotourism sites in developing nations. Trends 31: $10-15$.

Loomis J.B. and A. Gonzalez-Caban. 1997. How certain are visitors of their economic values of river recreation: An evaluation using Repeated Questioning and Revealed Preference. Water Resources Research 33:1187-1193.

Mohd Azim M.I., A.G. Awang Noor, H.O. Mohd Shahwahid, M. Salleh, N. Abdul Rahim and P. Ahmad Fauzi. 2002. Methods for valuation of NTFPs and environmental services. In N. Abdul Rahim (ed.) a 
model project for cost analysis to achieve sustainable Forest management. volume II, Main report. Pp 115-166.

Nasi R., Cassagne B.; Billand A. 2006. Forest management in Central Africa: where are we? International Forestry Review 8(1): 14-20.

Pieter J.H. Van Beukering, Herman S.J. Caesar and Marco A. Janssen. 2002. Economic valuation of the Leuser National Park on Sumatra, Indonesia. Ecological Economics 44 (2003): 43-62.

Schultz S., Pinazzo J. and Cifuentes M. 1998. Opportunities and limitations of contingent valuation surveys to determine national park entrance fees: evidence from Costa Rica. Environment and Development Economics 3: 131-149.

Spergel B. 2001. Raising revenues for protected areas. A Menu of options. Center for Conservation Finance. World Wildlife Fund. 28pp.

SPSS User Guide. 1999. SPSS Base 9.0. User Guide. SPSS Inc. Marketing Department. Chicago. USA. ISBN: 1-56827-832-2. pp. 276-394.

Tieguhong J.C. 2003. Review and Synthesis of fee mechanisms for Non-wood forest products and forest services in Africa. Africa Outlook Studies on Forest Finance. EC-FAO Partnership Programme (20002002). Consultancy Report. 59 pp.

Tieguhong J.C. and Ndoye O. 2004. Wildlife and protected areas management in Central Africa: Major challenges and ways forward. Paper presented at the Vth Conference on Central African Moist Forest Ecosystems (CEFDHAC) in Yaounde, Cameroon. 24-26 May 2004.

Usongo. L. 1998. Conservation Status of Arboreal Primates, Lobéké Forest, SE Cameroon. Primate Conservation 18: 66-68.

Usongo L. 2002. Apes in the Proposed Tri-National de la Sangha Conservation Area. Gorilla Journal 25: 49.

van Germerden B.S. 2004. Disturbance, diversity and distributions in Central African rain forest. Ph.D thesis. Department of Environmental Sciences. Wageningen University, the Netherlands. ISBN 905808-966-5. $200 \mathrm{pp}$.

Wilkie D.S. and Carpenter J.F. 1999a. Can nature tourism help finance protected areas in the Congo Basin? Orynx 33: 332-338.

Wilkie D.S. and Carpenter J.F. 1999b. The potential role of safari hunting as a source of revenue for protected areas in the Congo Basin. Orynx 33. 339-345.

Wilkie S.D., Carpenter J.F. and Zhang Q. 2001. The under-financing of protected areas in the Congo Basin: so many parks and so little willingness-to-pay. Biodiversity and Conservation 10: 691-709.

Whitehead J.C. 2003. Improving willingness to pay estimates for quality improvements through joint estimation with quality perceptions. Appalachian State University. 26 pp.

Yunis E. 2003. Sustainable Development of Tourism: Remarks at symposium on natural resource conservation \& economic development in the Congo Basin: The Role of Ecotourism. WTO. February 21. http://www.state.gov/g/oes/rls/rm/2003/25826.htm 